\title{
Profil Komoditas Kacang Mete dan Jagung di Pulau Muna Provinsi Sulawesi Tenggara
}

\author{
Reginawanti Hindersah ${ }^{1}$, Nini Mila Rahmi \\ ${ }^{1}$ Fakultas Pertanian Universitas Padjadjaran. Jalan Raya Bandung Sumedang Km. 21 Jatinangor, Sumedang 45363 \\ ${ }^{2}$ Fakultas Pertanian Universitas Halu Oleo. Kampus Hijau Bumi Tridharma Anduonou Kendari 93132 \\ Email korespondensi: reginawanti@unpad.ac.id
}

\begin{abstract}
ABSTRAK
Bentang lahan perbukitan batu gamping dikenal dengan nama bukit karst di Pulau Muna menumbuhkan tanaman lokal Jambu Mede (Anacardium occidentale L.) yang menghasilkan kacang mete. Wilayah karst ini juga mendukung pertumbuhan tanaman pangan lokal seperti jagung. Produk lokal ini perlu dipertahankan untuk menggerakan ekonomi masyarakat dan memberikan identitas Pulau Muna sebagai penghasil kacang mete dan jagung. Jambu Mete dan jagung adalah komoditas unggulan di Pulau Muna. Artikel ini menjelaskan kondisi budidaya serta potensi ekonomi jambu mete dan jagung di Pulau Muna.. Namun untuk mencapai produksi dan nilai jual optimalnya, adopsi teknologi di kebun dan pasca panen terutama kacang mete masih perlu ditingkatkan.
\end{abstract}

Kata kunci: Jagung, Kacang Mete, Muna, Produk Lokal, Produktivitas.

\section{Profile of Cashew and Corn in Muna Island, Sulawesi Tenggara Province}

\begin{abstract}
The limestone hilly landscapes, well known as karst hills, in Muna Island resulted in natural grow of cashew (Anacardium occidentale L.). The karst area alos support the cultivation of local food crops such as maize. Both local products need to be maintained in order to increase the community's revenue and give the identity to Muna Island as cashew nuts and maize producer. Cashew and maize are the leading commodities of Muna Island. This article describes the cultivation conditions and economic value of cashew nuts and maize in Muna Island. However, to achieve optimal production and selling value, technology adoption either in the field or post-harvest, needs to be improved especially for cashew.
\end{abstract}

Keyword: Maize, Cashew, Muna, Local Commodities, Productivity

\section{PENDAHULUAN}

Muna, sebuah pulau yang berdampingan dengan Pulau Buton, menyimpan banyak harapan bagi Provinsi Kepulauan Sulawesi Tenggara (Gambar 1). Di masa lalu, abad ke 15, Muna ditempati oleh Kerajaan Muna yang terdengar cukup asing dibandingkan saat kita mendengar nama Kerajaan Buton yang berdiri setelah Kerajaan Muna. Di Era Desentralisasi dan Pemekaran Daerah, Pulau Muna terbagi menjadi bagian dari tiga Kabupaten yaitu Kabupaten Muna, Muna Barat dan Buton Selatan.
Pulau Muna adalah salah satu pulau di Indonesia yang juga dikelilingi oleh beberapa Pulau lebih kecil. Salah satu konsep penting pada pembangunan wilayah kepulauan, adalah penduduk pulau memiliki pengetahuan dan keterampilan memadai untuk mandiri dalam beberapa hal penting terutama penyediaan pangan. Produksi pangan lokal menjadi wacana penting untuk masyarakat kepulauan. Pada dasarnya, saat penduduk belum banyak dan kehidupan masih sederhana, pangan lokal menjadi kekuatan pemenuhan konsumsi sehari-hari. Pergeseran nilai budaya termasuk budaya makan (food habit) menyebabkan, 
tanpa disadari, bahan pangan diimpor dari luar pulau dan melemahkan ketahanan pangan. Pengetahuan kolektif mengenai konsep pembatasan pangan impor dan penguatan produksi pangan lokal perlu diperkuat bukan saja di tatanan pemerintah setempat tetapi juga di masyarakat. Dengan sejarah yang panjang, Pulau Muna memiliki potensi ekonomi yang baik dilihat dari kearifan lokal pertanian.

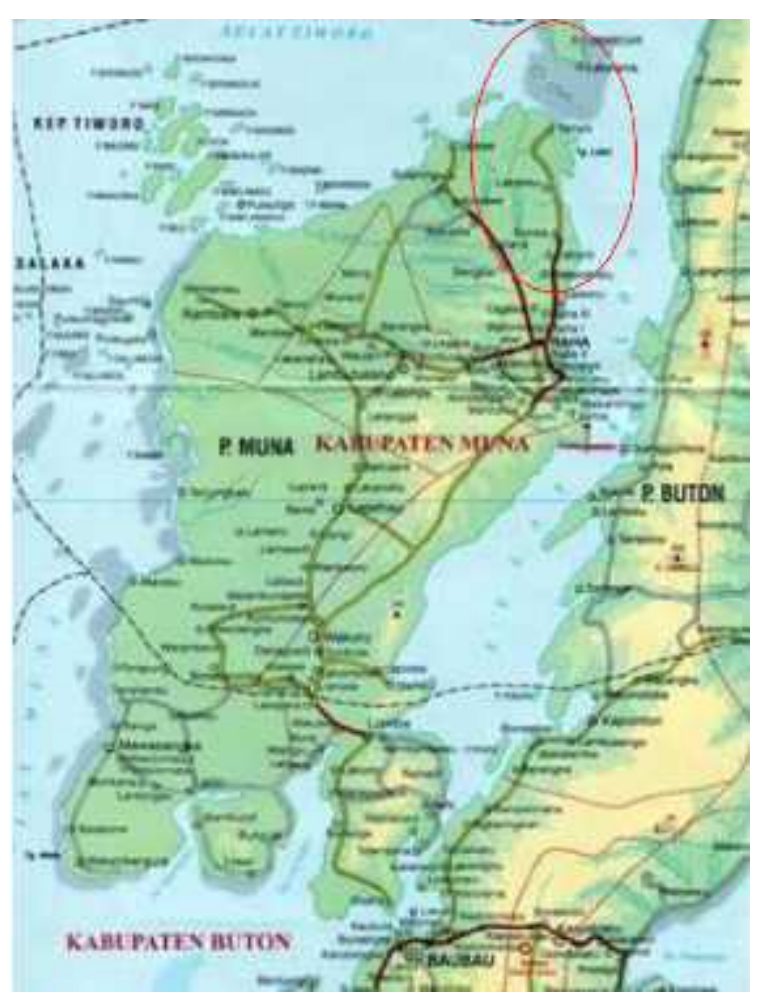

Gambar 1. Pulau Muna di sebelah Pulau Buton; dengan lokasi studi di dalam lingkaran merah

Pulau Muna memiliki bentuk bentang lahan perbukitan batu gamping dikenal dengan nama bukit karst. Lahan dengan batuan induk batu gamping menumbuhkan tanaman lokal Jambu Mete yang menghasilkan kacang mete. Patahan bukit karst membentuk dolina dimana sedimen pelapukan batu gamping menumpuk dan menjadi tempat yang baik untuk pertanaman tanaman pangan lokal seperti jagung dan sayuran/palawija. Produk lokal ini perlu dipertahankan untuk menggerakan ekonomi masyarakat dan memberikan identitas Pulau Muna, terutama produk pangan lokal. Artikel ini menjelaskan unggulan pertanian tanaman penting di Muna yang dapat mendukung ketahanan pangan dan ekonomi keluarga yaitu jambu mete dan jagung. Kacang mete Muna dikenal berkualitas karena berukuran besar, putih dan utuh; dan sejak lama telah menjadi sumber pendapatan Pulau Muna. Di lain pihak, jagung lokal belum banyak dikenal tetapi menjadi sumber inspirasi untuk penguatan produksi jagung di Muna.

\section{BAHAN DAN METODE}

Artikel disusun berdasarkan data primer dan sekunder. Data primer diperoleh dari survey lapangan dan wawancara dengan petani kacang mete di sentra produksi Mete di Kabupaten Muna termasuk Pulau Towea dan 
jagung lokal di sekitar kota Raha pada bulan September 2016. Data sekunder diperoleh dari studi pustaka ilmiah, ilmiah populer maupun dokumen resmi dari Pemerintah Daerah serta Kementrian Pertanian terutama Badan Litbang Pertanian.

\section{HASIL DAN PEMBAHASAN}

\section{Jambu Mete (Anacardium occidentale L.)}

Jambu mete yang menghasilkan kacang mete adalah bagian dari produk pangan Muna dengan keunggulan komparatif tingi. Tanaman jambu mete dapat dikembangkan di Muna yang beriklim cukup kering dan lahan marginal dengan tingkat kesuburan yang rendah ${ }^{[1]}$. Curah hujan Muna di bawah 2.000 $\mathrm{mm} / \mathrm{thn}$ mendukung proses pembentukan buah jambu mete. Pada tahun 2015 produksi kacang mete dari perkebunan rakyat di Pulau Muna, mencapai 8.507 t yang dipanen dari kebun jambu mete milik petani seluas 21.582 ha dengan melibatkan 27.762 petani; padahal kebun jambu mete di Muna mencapai 31.989 ha ${ }^{[2]}$. Produksi kacang mete Muna pada 2017 memberikan sumbangan $29,5 \%$ terhadap besarnya produksi komoditas ekspor ini di Sulawesi Tenggara.

Mete di Muna awalnya ditanam untuk kepentingan konservasi lahan kritis dan gersang, bukan untuk tujuan budidaya dan produksi. Hal tersebut menjadi program dari Bupati Muna La Ode Kaimoeddin tahun 1970an. Karena unutuk tujuan konservasi, jarak tanam yang digunakan $5 \mathrm{~m} \times 5 \mathrm{~m}$ dan tanpa ada pemupukkan dan pemeliharaan khusus. Nanti sekitar tahun 2000-an Dinas Pertanian menganjurkan penanaman mete dgn jarak 10 $\mathrm{m} \times 10 \mathrm{~m}$. Namun, hal tersebut tidak terlalu menguntungkan bila penanamannya menggunakan pola intercropping. Jarak tanam ideal untuk penanaman sistem intercropping sekitar $7 \mathrm{~m} \mathrm{x} 14 \mathrm{~m}$.

Lokasi utama tanaman jambu mete di Muna adalah di Desa Lahontohe dan Desa Labasa Kecamatan Tongkuno sedangkan pengolahan kacang mete di desa Mabodo Kecamatan Kotunaga, serta di Kecamatan Towea. Rendahnya produksi karena di wilayah Pulau Muna, termasuk di Pulau Towea yang terletak di sebelah utara Pulau Muna disebabkan banyak pohon jambu mete berumur tua dengan produksi rendah (Gambar 2). Pada tahun 2015, Kab. Muna memiliki 2.235 ha lahan pertanaman kacang mete yang belum menghasilkan (TBM), 21.582 ha tanaman menghasilkan (TM) dan 12.172 ha kebun yang rusak ${ }^{[2]}$. Perluasan pohon jambu mete memerlukan biaya besar yang menurut Dinas Pertanian, tidak terjangkau oleh masyarakat.

Pohon jambu mete di Muna awalnya ditanam untuk kepentingan konservasi lahan kritis dan gersang, bukan untuk tujuan budidaya dan produksi. Perbaikan lahan tersebut menjadi program Bupati Muna La Ode Kaimoeddin tahun 1970-an dengan Jarak tanam $5 \mathrm{~m} \times 5 \mathrm{~m}$; tanpa pemupukan dan tanpa pemeliharaan karena tujuan penanaman bukan untuk produksi kacang mete. Tanaman jambu mete di Pulau Muna didominasi oleh tanaman tua berumur lebih dari 25 tahun bahkan 50 tahun. Di Pulau Towea budidaya jambu mete mulai dilakukan para mandor mantan pengelola perkebunan kelapa dalam milik negara menguasai lahan yang ditinggalkan pada 1990-an (Gambar 2).

Produktivjtas tanaman tidak pernah optimal; namun tetap menguntungkan. Di Muna, belum ada perkebunan mete swasta yang dikelolah secara profesional. Para petani pemilik pohon jambu mete hampir tidak pernah memelihara pohon yang sesungguhnya merupakan aspek penting dalam menjaga produktivitas pohon. Beberapa petani secara perorangan sudah mulai membudidayakan mete secara intensif dengan menggunakan teknik budidaya yang baik, meliputi pengaturan jarak tanam, teknik penanaman dan pemupukkan serta metode pemeliharaan yang tidak lagi bersifat tradisional. Produksitvitas masih rendah tetapi bagi petani, menanam jambu mete lebih menguntungkan daripada padi. 

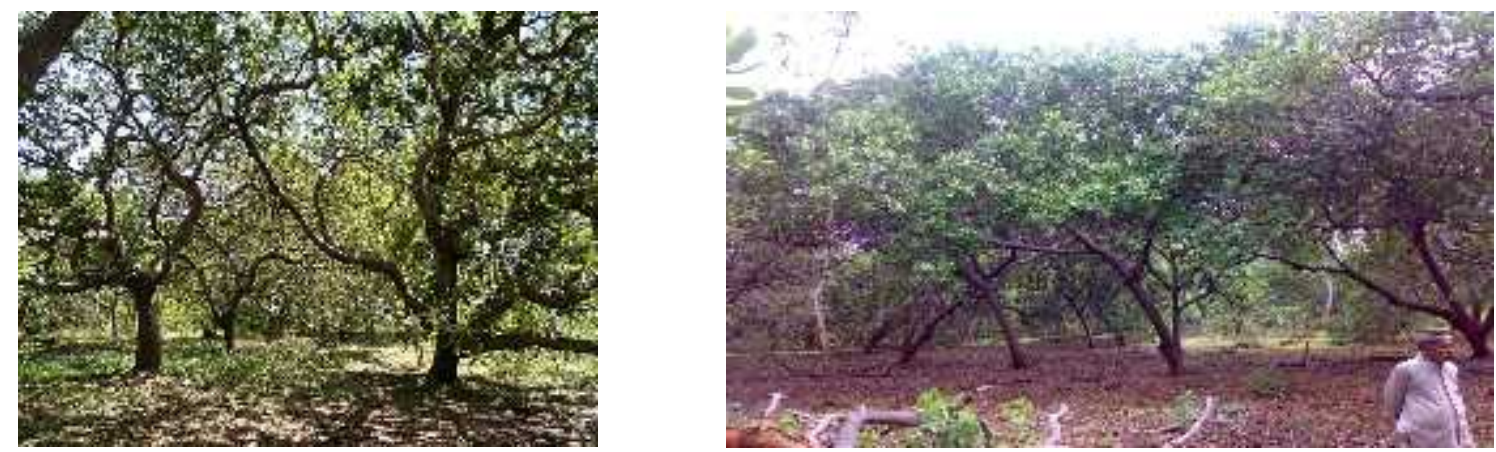

Gambar 2. Tanaman jambu mete berumur lebih dari 25 tahun di Pulau Towea (kiri) dan tanaman berumur sekitar 10 tahun di Pulau Muna (kanan)

Petani tradisional menggunakan bibit asalan, mereka biasanya mengambil biji dari tanaman induk miliknya yang diseleksi sebelum tanam. Sebenarnya, sumber benih jambu mete varietas Muna ada di Blok Penghasil Tinggi (BPT)/Pohon Induk Terpilih (PIT) yang berumur relatif tua. Untuk menjaga kualitas bibit, telah dibangun kebun induk seluas 5 ha yang ditetapkan oleh Kementrian Hukum dan HAM RI di Kecamatan Parigi Kabupaten Muna. Tanaman jambu mete di kebun induk tersebut bersumber dari benih asal grafting dengan batang atas (entres) dan batang bawah dari populasi yg sama ${ }^{[3]}$. Sebagian besar petani di Muna menggunakan entres pecah tunas. Sumber entres demikian hanya efektif bila penyambungan dilakukan di tempat yg sama dengan sumber batang bawah. Balai Penelitian Tanaman Rempah dan Obat tetap menggunakan entres dengan tunas tidur/flush, mengingat resiko kerusakan entres pecah tunas selama pengemasan dan pengiriman cukup tinggi.

Location Quotient (LQ), tanaman jambu mete di Sulawesi Tenggara mencapai 36,37, membuktikan bahwa jambu mete merupakan komoditas unggulan di Sulawesi Tenggara [3]. Pengembangan komoditi jambu perlu dilakukan untuk mendukungnya permintaan ekspor yang tinggi dari Amerika, Belanda, Inggris, Jerman, Australia, Hong Kong, Singapura, Taiwan, Cina, dan Jepang ${ }^{[1]}$. Sulawesi Tenggara memiliki kebun jambu mete 27\% dari total area tanaman mete nasional. Pada tahun 2015, Indonesia mengekspor $104.647 \mathrm{t}$ mete senilai 184.395 ribu US\$ yang menjelaskan pentingnya kacang mete untuk perekonomian nasional ${ }^{[2]}$. Peluang ini tidak dapat digapai karena produksi yang rendah, pendapatan rendah dan sistem pemasaran yang tidak efisien dan posisi tawar petani lemah sehingga harga jual di tingkat petani rendah ${ }^{[4]}$.

Sekitar $36 \%$ produksi mete diekspor dalam bentuk gelondongan ${ }^{[1]}$, dengan harga jual paling rendah sehingga diperlukan industri kecil maupun menengah untuk pengolahan kacang mete disertai penembangan alat pengupas kulit mete yang lebih efisien. Mete Indonesia disukai pasaran dunia karena berkualitas prima yaitu lebih besar, lebih putih dan lebih enak sehingga harganya tertinggi antara 25 negara produsen kacang mete. Kacang mete Muna umumnya masih dijual dalam bentuk gelondongan yang kurang memiliki nilai tambah dibandingkan dengan kacang mete olahan; sehingga keunggulan kompetitif mete Muna masih rendah.

Harga biji mete gelondongan berkulit saat ini Rp. 20.000 - Rp. 25.000 per kg, lebih rendah daripada kacang mete mentah tanpa kulit sekitar Rp. 80.000- Rp. 140.000 tergantung dari musim panen dan kualitas kacang. Harga mete tanpa kulit dapat mencapai $2-5$ kali lipat dari harga mete mentah tanpa kulit tetapi tetapi ekspor terbesar adalah mete gelondongan. Namun harga sangat berfluktuatif dan ditentukan oleh pedagang. Pada awal September 2019, hara mete gelomdongan hanya Rp. 5.000/kg dan meningkat menjadi Rp. $10.000 / \mathrm{kg}$ di akhir bulan. Pada tahun sebelumnya, mete gelondongan dapat dijual oleh petani seharga 
Rp.18.000-Rp. 22.000/kg dan mete olahan Rp.120.000/kg.

Di Kabupaten Muna, sedikitnya ada 1.000 industri pengupas mete; $85 \%$ mengunakan alat sederhana, yaitu kacip yang terbuat dari besi dan kayu (Gambar 3). Pengupasan dengan kacip menyebabkan menurunkan kualitas; 30\% kacang mete terbelah ${ }^{[5,6]}$; juga tidak efisien karena setiap orang hanya mengupas $1-1,5 \mathrm{~kg}$ mete gelondongan per jam untuk memperoleh 0,25 $0,375 \mathrm{~kg}$ kacang mete ${ }^{[6]}$. Fluktuasi harga dapat ditekan dengan meningkatkan produksi metea kulas (olahan) namun keterbatasan kacip menjadi kendala. Peluang investasi untuk sektor ini selain produk olahan kacang mete matang, juga produksi jus dari buah semu dan minyak laka dari kulit biji mete. Minyak laka mengandung kardanol sebagai antioksidant yang mengandung asam anakardan, kardol, kardanol, 2- methyl kardol, dan polymer; dan telah diekspor ke manca negara ${ }^{[7]}$.
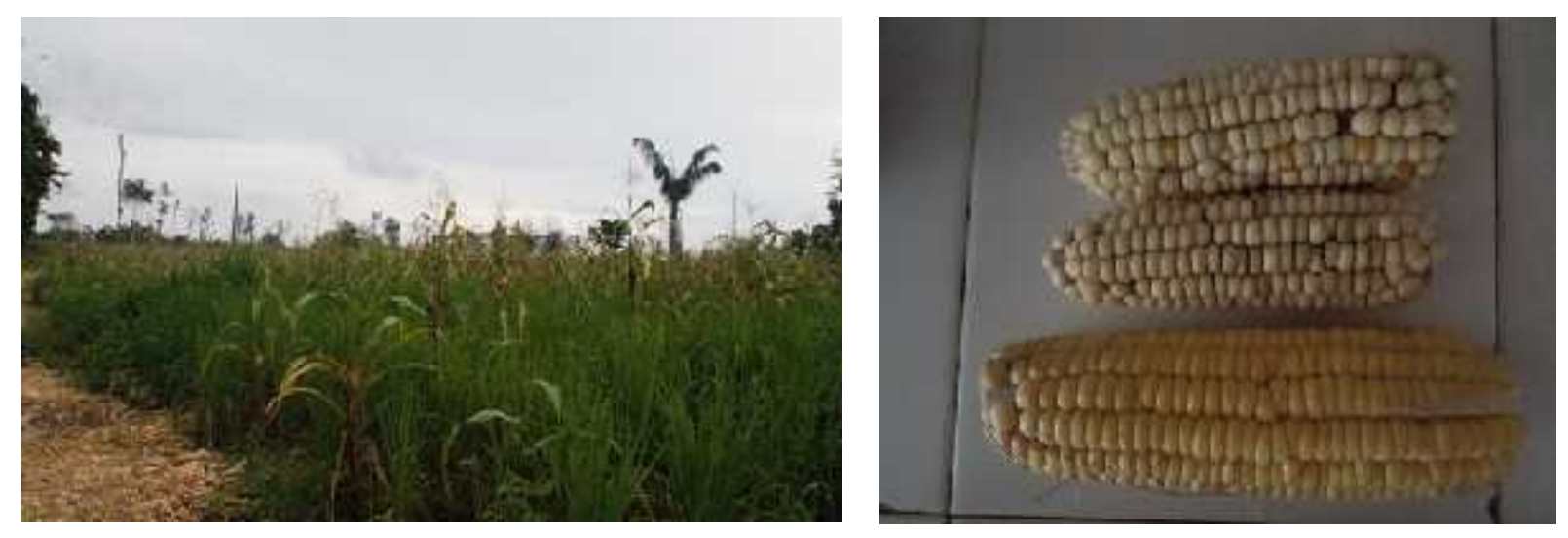

Gambar 3. Tanaman jagung lokal di Kabawo, Muna (foto Yasmin Indas), jagung lokal berwarna dan berukuran lebih kecil daripada jagung hibrida

Hampir setiap kepala keluarga di Muna memiliki lahan kebun jagung paling tidak satu hektar. Setidaknya rumah tangga di Muna terlihat menanam jagung lokal di halaman dalam jumlah terbatas untuk konsumsi keluarga (Gambar 4). Jagung lokal berumur pendek mengandung lebih banyak protein sehingga ada gagasan pembuatan dodol dan susu jagung dari jagung lokal.

\section{Jagung (Zea mays L.)}

Jagung varietas lokal pernah menjadi makanan pokok penduduk Muna dan di beberapa lokasi masih menjadi bahan pangan utama (staple food) di Sulawesi Tenggara. Komoditas pangan lokal secara alami tumbuh dengan baik di sedimen di antara batu gamping. Penduduk Muna hanya mengkonsumsi jagung lokal berumur genjah (sekitar 2 bulan). Berdasarkan umur panen, ada dua jenis jagung lokal (belum diberi nama) yaitu jagung berumur panen 65 hari dan 75 hari. Jagung lokal berwarna putih dengan ukuran lebar sekitar $5 \mathrm{~cm}$ dan panjang sekitar 10-12 cm (Gambar 3), mengandung protein tinggi saat muda, amilopeptin lebih tinggi daripada jagung hibrida (kuning). Amilopektin berpengaruh terhadap tekstur dan rasa.; semakin tinggi kandungan amilopektin, tekstur dan rasa jagung semakin lunak, pulen, dan enak ${ }^{[8]}$. 

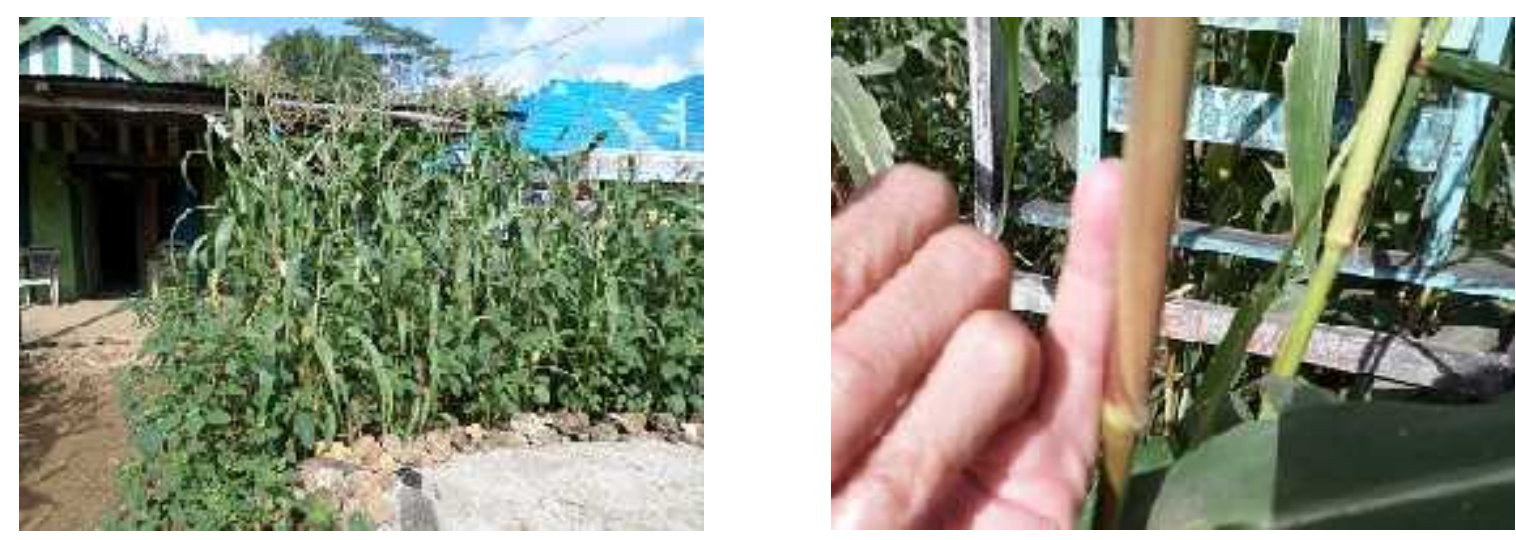

Gambar 4. Masyarakat Muna menanam jagung di halaman rumah tanpa pemeliharaan intensif

Pada tahun 2011, luas areal pertanaman jagung di Sulawesi Tenggara adalah 31.222 ha dengan produktivitas hanya 2,54 t/ha (Abidin dan Ratule, 2013) karena adopsi teknologi masih rendah. Pengelolaan Tanaman Terpadu komoditas jagung yang rendah di tingkat petani; hanya 58,33\% di Kabupaten Muna ${ }^{[10]}$. Nilai LQ jagung di Sulawesi Tenggara $>1$ yang mengindikasikan jagung dapat menjadi komoditas utama di Muna selain Kabupaten Buton Kolaka Utara, dan Kota Kendari [11]. Namun tingkat perkembangan tanaman jagung lambat meskipun jagung memiliki keunggulan komparatif wilayah berdasarkan nilai Komponen Pertumbuhan Wilayah di Kabupaten Muna ${ }^{[11]}$.

Balai Pengkajian Teknologi Pertanian (BPTP) telah banyak melakukan uji adaptasi, pengkajian dan desiminasi teknologi spesifik lokasi dan sudah banyak juga teknologi yang direkomendasikan untuk dikembangkan di wilayah Sultra. Pada tahun 2010 dilakukan pendampingan Sekolah Lapang Pengelolaan Tanaman Terpadu (SLPTT) sebanyak 12 unit. Namun, petani belum mengadopsi teknologi yang direkomendasikan mungkin karena faktor sosial ekonomi, selain perubahan teknik tanam selalu tidak mudah.

Introduksi jagung hibrida telah dilakukan sejak sekitar tahun 1970. Dengan target sangat tinggi, 6 ton/ha khususnya Kecamatan Tiworo akan menjadi lokasi kebun jagung hibrida yang disebut jagung kuning oleh masyarakat Muna. Bekerjasama dengan pengusaha, budidaya jagung akan terintegrasi dengan pascapanen. Mekanismenya adalah petani menjual langung kepada pengusaha untuk menghindarkan kerugian. Dalam program tersebut, sebagian lahan yang terolah setiap tahun harus ditanami jagung hibrida yang hasilnya untuk diperdagangkan, sedang lahan sisanya tetap ditanami jagung lokal untuk konsumsi sendiri.

Dinas Pertanian melakukan penyuluhan dan mengawal program intensifikasi jagung hibrida di lahan masyarakat dengan bantuan pusat; dan pernah gagal mencapai target. Namun pada 2015, luas panen jagung di Kabupaten Muna telah mencapai 13.159 ha, dengan produksi 32.007 ton dan produktivitas 2,43 t/ha setelah dilakukan pemupukan ${ }^{[12]}$. Nilai B/C Usahatani jagung hibrida Bima 19 URI dan jagung lokal di Muna masing nilai $\mathrm{B} / \mathrm{C} 1,07$ dan 1,17; menguntungkan, tetapi produktivitas jagung hibrida dan pendapatan usahatani jagung hibrida lebih tinggi daripada jagung lokal ${ }^{[12]}$.

Model Pemberdayaan Masyarakat yang dapat diusulkan untuk optimasi produksi hibrida adalah melalui perencanaan produksi jagung terintegrasi dengan kebutuhan dan sektor lain, penguatan kelembagaan yang melibatkan Pemerintah-Pelaku (Masyarakat)Pengusaha dengan konsep distribusi keuntungan yang merata di antara pelaku. Produksi pakan ternak berbasis jagung akan 
mendorong peternakan unggas, ayam petelur dan ayam potong lokal yang 20 tahun lalu pernah ada. Produksi tersebut dipasarkan ke Kota Kendari dan Bau-Bau. Saat ini Muna impor telur dari Sidenreng Rappang (Sidrap), Sulawesi Selatan sebanyak120.000 butir telur per bulan. Penguatan kelembagaan perlu melibatkan tokoh pemberdayaan masyarakat setempat yang memperkuat potensi perubahan perilaku petani untuk menerapkan teknologi. Tokoh yang kuat akan menghasilkan kader dan partisipan program. Di awal program mungkin masih perlu penguatan modal/sarana dari pemerintah.

Selain kendala sosial karena keterbatasan minat petani menanam padi hibrida, dua hambatan utama untuk meningkatkan produksi jagung baik hibrida maupun lokal adalah:

\section{Kekeringan}

Kekurangan air kerap melanda pertanaman jagung karena sistem budidaya masih tadah hujan. Untuk jagung hibrida berumur panjang kekeringan lebih mengancam daripada untuk jagung lokal berumur genjah 2 bulan. Kabupaten Muna merupakan sentra pertanaman jagung, sekitar 99\% pertanaman jagung dilakukan di lahan kering ${ }^{[11]}$. Sementara ini potensi lahan lain misalnya lahan sawah belum optimal dimanfaatkan. Pada 2015, dari 400 ha lahan yang ditanami kedelai dan jagung di Kabupaten Muna, sekitar 60 ha di antaranya sudah kering. Pemda selalu menyarankan agar masyarakat yang memiliki sumur pompa dapat membantu menyediakan air dan agar air digunakan optimal.

2. Keterbatasan Penerapan Teknologi

Rendahnya produktivitas jagung disebabkan oleh berbagai faktor diantaranya adalah masih rendahnya penerapan teknologi. Hal ini menunjukkan bahwa adopsi teknologi jagung di Kabupaten Muna Sulawesi Tenggara masih berada pada kategori sedang ${ }^{[11]}$. Teknologi yang kurang diadopsi selain akibat keterbatasan akses ke input pertanian dan peralatan pertanian, juga dapat disebabkan oleh tingkat penerimaan masyarakat terhadap teknologi baru yang sebatas taraf perubahan pengetahuan.

Harapan sebenarnya ada di budidaya jagung lokal yang lebih diterima untuk dikonumsi oleh penduduk Muna. Dalam DAK APBN 2016, Dinas Pertanian Kabupaten Muna sudah memasukkan intensifikasi budidaya jagung lokal. Modal pemberdayaan untuk jagung lokal, adalah perubahan branding dari "Jagung Lokal" menjadi "Jagung Unggulan Berkualitas". Jagung lokal dapat dijadikan ikon Muna karena kualitasnya memenuhi apa yang disebut sebagai makanan fungsional. Langkah awal dari branding adalah memberikan pemahaman dan pengetahuan kepada masyarakat dengan tujuan lebih menghargai jagung lokal. Belum ada demplot optimasi budidaya jagung lokal, padahal langkah ini penting untuk menunjukkan bahwa jagung lokal memiliki keunggulan komparatif.

\section{KESIMPULAN}

Perekonomian Muna telah digerakan secara tradisional oleh komoditas unggulan Jambu Mete yang kualitasnya diakui dunia. Komoditas pertanian penting lainnya adalah jagung lokal yang saat ini tidak berkembang untuk mendukung perekonomian kabupatenkabupaten di Muna; jagung lokal terpinggirkan oleh jagung hibrida. Kedua komoditas, Jambu Mete dan Jagung Hibrida mendapatkan pengawalan dari Kementrian Pertanian untuk dapat mencapai produktivitas yang optimal. Secara umum, produktivitas kedua komoditas belum optimal karena adopsi teknologi masih rendah.

Kacang mete Muna sangat diterima oleh pasar lokal dan ekspor tetapi produktivitas dibatasi oleh umur tanaman yang relatif tua karena peremajaan memerlukan dana yang tidak terjangkau petani; dan pengeloaan kebun yang belum intensif. Produksi tanaman jambu mete Muna yang 
rendah tidak diikuti dengan peningkatan kualitas kacang mete untuk meningkatkan nilai tambah. Kacang Mete diekspor dalam bentuk gelondongan dengan harga lebih rendah karena keterbatasan kualitas alat pemecah kulit mete. Untuk jagung hibrida, manajemen kebun, pemeliharaan tanaman dan pasca panen yang belum sesuai PTT menyebabkan produktivitas umumnya masih di bawah $6 \mathrm{t} / \mathrm{ha}$. dan kualitas, dan pasar dan pola pertanaman untuk optimasi lahan setelah rehabilitasi tanaman jambu mete. Langkah pertama untuk meningkatkan produktivitas komoditas unggulan adalah kerjasama yang terstruktur dari setiap stake holder yang diharapkan akan menjaga produktivitas, kualitas dan nilai tawar petani.

\section{UCAPAN TERIMA KASIH}

Kami berterimakasih kepada Badan Perencanaan dan Pengembangan Daerah Kabupaten Raha atas izin melaksanakan kajian yang dibiayai melalui program Bhakesra Kementrian Koordinator Pembangunan Manusia dan Kebudayaan pada 2016.

\section{DAFTAR PUSTAKA}

[1] Rahni, N.M.. La Karimuna, Asmin. 2016. Pengembangan Agroindustri Jambu Mete di Provinsi Sulawesi Tenggara. Makalah presentasi pada Seminar Jambu Mete Nasional II "Revitalisasi Agroindustri Jambu Mete dalam Rangka Meningkatkan Daya Saing dan Nilai Tambah secara Berkelanjutan”, Bogor, 12-13 Oktober 2016.

[2] Hendaryati, D.D. dan Y. Arianto. 2017. Statistik Perkebunan Indonesia 20152017: Jambu Mete. Direktorat Jenderal Perkebunan, Kementrian Pertanian.

[3] Sutisna, E., Witjaksono, J dan J., A. Sulle 1999. Pemanfaatan lahan diantara Jambu Mete. Laporan hasil Penelitian. Proyek SAADP 1998/1999. Unpublished. BPTP Kendari

[4] Nurdiyah, N., Fariyanti, A. dan S. Jahroh. 2014. Analisis pemasaran jambu mete di Kabupaten Muna provinsi Sulawesi Tenggara. Informatika Pertanian, 23(1): 85-94

[5] Witjaksono J., dan Asmin. 2016. Agroindustri kacang mete di Sulawesi Tenggara: Potensi, kendala dan strategi pengembangannya . Prosiding Forum Komunikasi Nasional Jambu Mete II Bogor, 12-13 Oktober 2016. Hal 207214.

[6] Istiyanti, E., Suwanda, T. dan Sriyadi. 2018. Upaya peningkatan produktivitas pengrajin kacang mete dengan teknologi tepat guna alat pengupas mete di Kecamatan Imogiri Kabupaten Bantul. Prosiding Seminar Nasional PPM Universitas Ahmad Dahlan yogyakarta, 27 oktober 2018. Hal 105-110

[7] Suhartono, J., Noersalim, C., Sinaga, D.P. dan D. Triyana. 2010. Pengambilan minyak laka dari kulit biji mete dan peningkatan kandungan kardanol dalam minyak laka. Seminar Rekayasa Kimia dan Proses, Jurusan Teknik Kimia Fakultas Teknik Universitas Diponegoro, Semarang 4-5 Agustus 2010, c-15:1-4

[8] Suarni, S. dan Widowati. 2007. Struktur, Komposisi, dan Nutrisi Jagung dalam Hermanto, Suyamto, dan Sumarno (Ed). Jagung: Teknik Produksi dan Pengembangan. Hal 410-426.

[9] Ronas. 2017. Petani Marobea, Muna Barat Panen Jagung Hingga 7 Ton Per HA.

https://koransultra.com/2017/05/02/pe tani-marobea-muna-barat-panenjagung-hingga-7-ton-per-ha/

[10] Abidin, Z. dan M.T. Ratule. 2013. Strategi pengembangan jagung di Sulawesi Tenggara. Seminar Nasional Serealia, Maros 18 Juni 2013.

[11] Abidin, Z. 2015. Posisi relatif komoditas jagung dalam perekonomian wilayah Sulawesi Tenggara. Prosiding Seminar Nasional Serealia, Malang 19 Mei 2015. Hal. 622-630 
Hindersah, R dan Rahmi, N.M. 2020. Profil Komoditas Kacang ...

[12] Suharno dan Rusdin. 2017. Kelayakan Jurnal Pengkajian dan Pengembangan usahatani jagung hibrida di Kabupaten Muna provinsi Sulawesi Tenggara. 